\title{
Studies on fruit set and fruit drop in sweet lime (Citrus limettioides TANAKA)
}

\author{
B. S. Chundawat and G. S. Randhawa \\ Indian Agricultural Research Institute, New Delhi, India
}

\section{Summary}

The investigations on fruit set and fruit drop in sweet lime (Citrus limettioides TANAKA) were carried out under Delhi conditions (North India) during the year 1962 64, at the Indian Agricultural Research Institute. The effect of GA,4-CPA, 2, 4-D and 2, 4, 5- $T$ at different concentrations on fruit set, fruit drop and quality of sweet lime was studied. Gib- berellic acid (750 and $1,000 \mathrm{ppm}$ ) gave the maximum fruit set followed by $2,4,5-\mathrm{T}(20 \mathrm{ppm}), \mathrm{GA}$ (500 $\mathrm{ppm})$ and 2, 4,5-T (7.5 and $10 \mathrm{ppm})$.

Plant growth regulator treatments proved ineffective against June drop. However, 2, 4-D (7.5 and $20 \mathrm{ppm})$ and $2,4,5-\mathrm{T}(7.5,10$ and $20 \mathrm{ppm})$ proved most effective against pre-harvest drop.

\section{Introduction}

The sweet lime (Citrus limettioides $\mathrm{T}_{\mathrm{ANAKA}}$ ) is an important citrus species grown commercially in North India. It bears sweet and juicy fruits but confronts two serious problems of poor fruit set and heavy fruit drop, which results in considerable reduction in yield. The first indication that specific substances might be involved in these steps by FitTing ${ }^{3)}$ led Gustafson ${ }^{4)}$ to conclude that synthetic auxins could induce fruit set in many species. Successful attempts were subsequently made to induce fruit set in different horticultural plants with the aid of synthetic plant growth regulators. When the fruit drop is not due to the lack of auxins in the fruits, plant growth regulators have been found ineffective against fruit drop ${ }^{2,5}$. However, if auxin level of the pedicel drops too low to prevent abscission, naturally plant growth regulator spray is effective ${ }^{5}$. Spray of $2,4-\mathrm{D}, 2,4,5-\mathrm{T}$ and $2,4,5-\mathrm{TP}$ have been found useful in improving fruit set and control fruit drop in many citrus species ${ }^{11,10,7)}$. From the various reports regarding the use of plant growth regulators on the fruit development process ${ }^{6}$, it is evident that the plant regulators play a key role in improving fruit set and minimizing fruit drop in different fruit crops. But very scanty informations on the role of plant growth regulators in sweet lime, especially under different soil and climatic conditions prevailing in this country are available. It is, therefore, present study was undertaken to investigate the effect of GA, 4-CPA, 2,4-D and 2,4,5-T on fruit set, fruit drop and quality of sweet lime under the Delhi conditions.

\section{Materials and Methods}

The present experiment was conducted on sweet lime, in the Experimental orchard of the Indian Agricultural Research Institute New-Delhi. Thirteen trees of uniform vigour and growth were selected and kept under uniform conditions of soil and orchard management.

Fruit set studies. Four concentrations each of gibberellic acid (250, 500, 750 and 1,000 ppm), Para-Chlorophenoxy acetic acid (50, 75, 100 and $200 \mathrm{ppm})$,2,4-Dichloro phenoxyacetic acid (5,

Received for publication January 20, 1971

* Present adress : Jaipur Udyog Ltd., Sawai Madhopur, Rajasthan, India 
7.5, 10 and $20 \mathrm{ppm}$ ) and 2,4,5-Trichlorophenoxyacetic acid (5, 7.5, 10 and $20 \mathrm{ppm}$ ) were tested in this study. Each tree was divided into four equal portions and every portion was considered as an unit. A number of branches were labelled for spraying. The treatments were replicated three times. Spraying was done on March 22, 1963 (full bloom) and data on fruit set were recorded after 20 days of spray.

Fruit drop studies. Four concentrations of each of GA (100, 500, 750 and 1,000 ppm), 4-CPA (25, 50, 75 and $100 \mathrm{ppm}), 2,4-\mathrm{D}(5,7.5,10$ and $20 \mathrm{ppm})$ and 2,4,5-T (5, 7.5, 10 and $20 \mathrm{ppm})$ were tested in this study. Each tree was divided into four equal portions and every portion was treated as a single unit. Treatments were replicated thrice following the simple randomized block design. Spray was done on May 1, 1963 against June drop and September 1, 1963 against pre-harvest drop. Data on fruit drop were recorded fortnightly until harvest.

Physico-Chemical Composition of fruit. The data on fruit size, fruit weight, fruit juice percentage and rind thickness were recorded just after harvest. The total soluble solids in juice were determined with the help of Zeiss hand refractometer at $20^{\circ} \mathrm{C}$.

Total acidity was determined by titrating $5 \mathrm{~m} l$ of juice against $\mathrm{N} / 100 \mathrm{NaOH}$ using phenolphthalein as an indicator.

For ascorbic acid, $25 \mathrm{~m} l$ of freshly extracted juice diluted to $100 \mathrm{~m} l$ by 3 percent metaphosphoric acid as stabilizing agent and aliquot of $5 \mathrm{ml}$ was titrated against standard indophenol dye.

Sugars were analysed as reducicg and non-reducing sugars by FeHLING solution method (A.O.A.C. 1960) and estimated in terms of glucose.

Statistical methods. The experiments were laid out on the randomized block design. All the treatments were replicated three times.

\section{Results}

Effect on fruit set. All the GA treatments increased the fruit set considerably and a gradual increase in fruit set was noted with the increase in the concentration. Para-Chlorophenoxyacetic acid also increased fruit set, but the rate of set decreased with the increase in concentrations. There was an increase in fruit set with increased concentration of 2,4-D upto $10 \mathrm{ppm}$ but then it declined at $20 \mathrm{ppm}$. All 2,4,5-T treatments increased the fruit set and a gradual increase in fruit set was observed with the increase in concentration but at the diminishing rate (Table 1, Fig. 1a). Among all the treatments GA (1,000 and $750 \mathrm{ppm})$ gave the maximum set followed by 2,4,5-T (20 ppm), GA (500 ppm) and 2,4,5-T (7.5 and $10 \mathrm{ppm})$.

Effect on fruit drop. (a) June drop: It is evident from Table 1 and Figure $1 \mathrm{~b}$ that none of the treatments could significantly reduce the June drop. Slight reduction in the June drop was observed in the treatments GA (750 and $1000 \mathrm{ppm}), 4-\mathrm{CPA}(50 \mathrm{ppm}), 2,4-\mathrm{D}(20 \mathrm{ppm})$ and 2,4,5-T (7.5 and $10 \mathrm{ppm})$. All other treatments increased it.

(b) Pre-harvest drop: Table 1 and Figure $1 \mathrm{c}$ shows that some of the treatments considerably reduced the fruit drop. All the GA treatments except GA (500 ppm) and the 4-CPA treatments except 4-CPA (25 ppm) increased the pre-harvest fruit drop. Of the 2,4-D treatments, 2,4-D $(7.5,10$ and $20 \mathrm{ppm})$ considerably reduced the pre-harvest drop. 2,4,5-Trichlorophenoxyacetic acid $(7.5,10$ and $20 \mathrm{ppm}$ ) also reduced the pre-harvest drop but an increase of 46.73 percent 
Table 1. Effect of plant regulators on fruit set, june drop and pre-harvest drop in sweet lime.

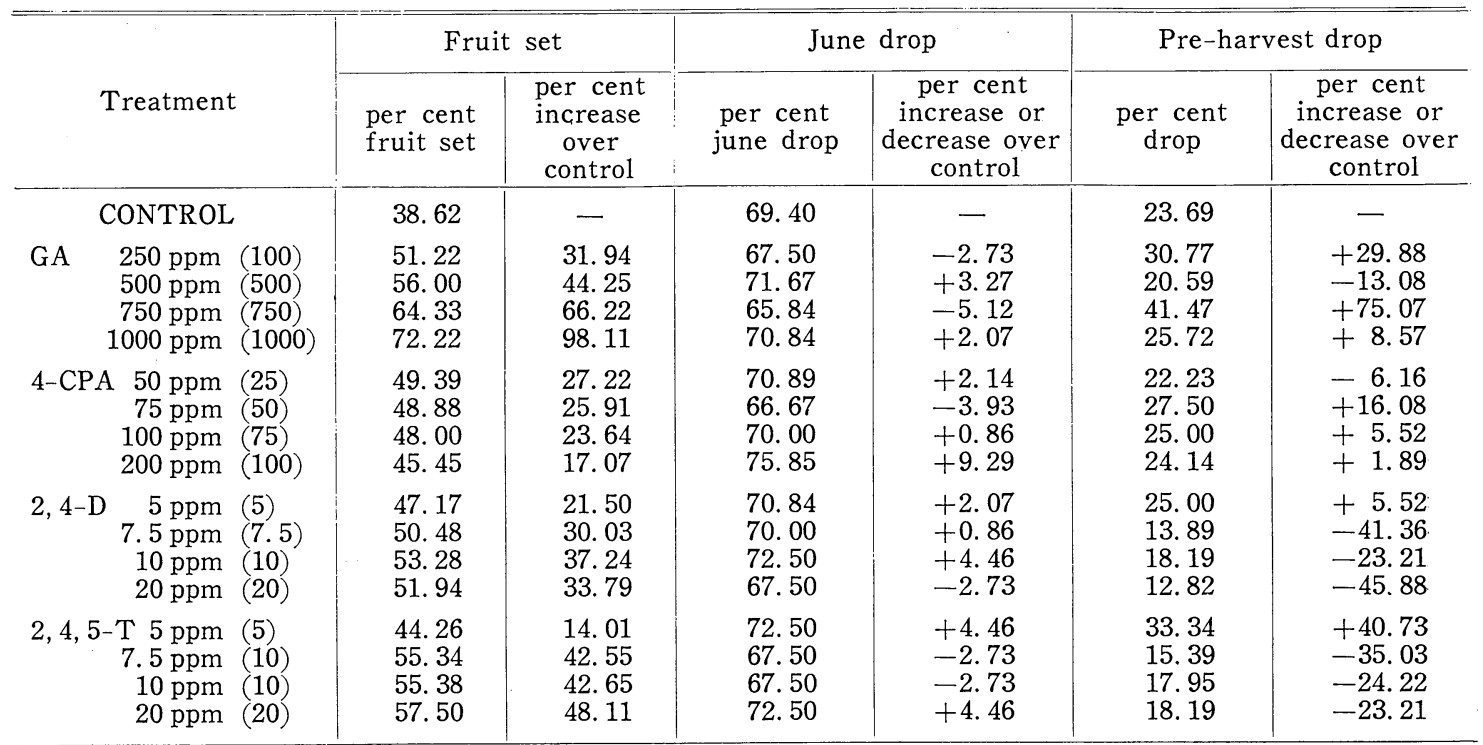

Note : Figures in parenthesis represent the concentration of plant growth regulators used against fruit drop studies.

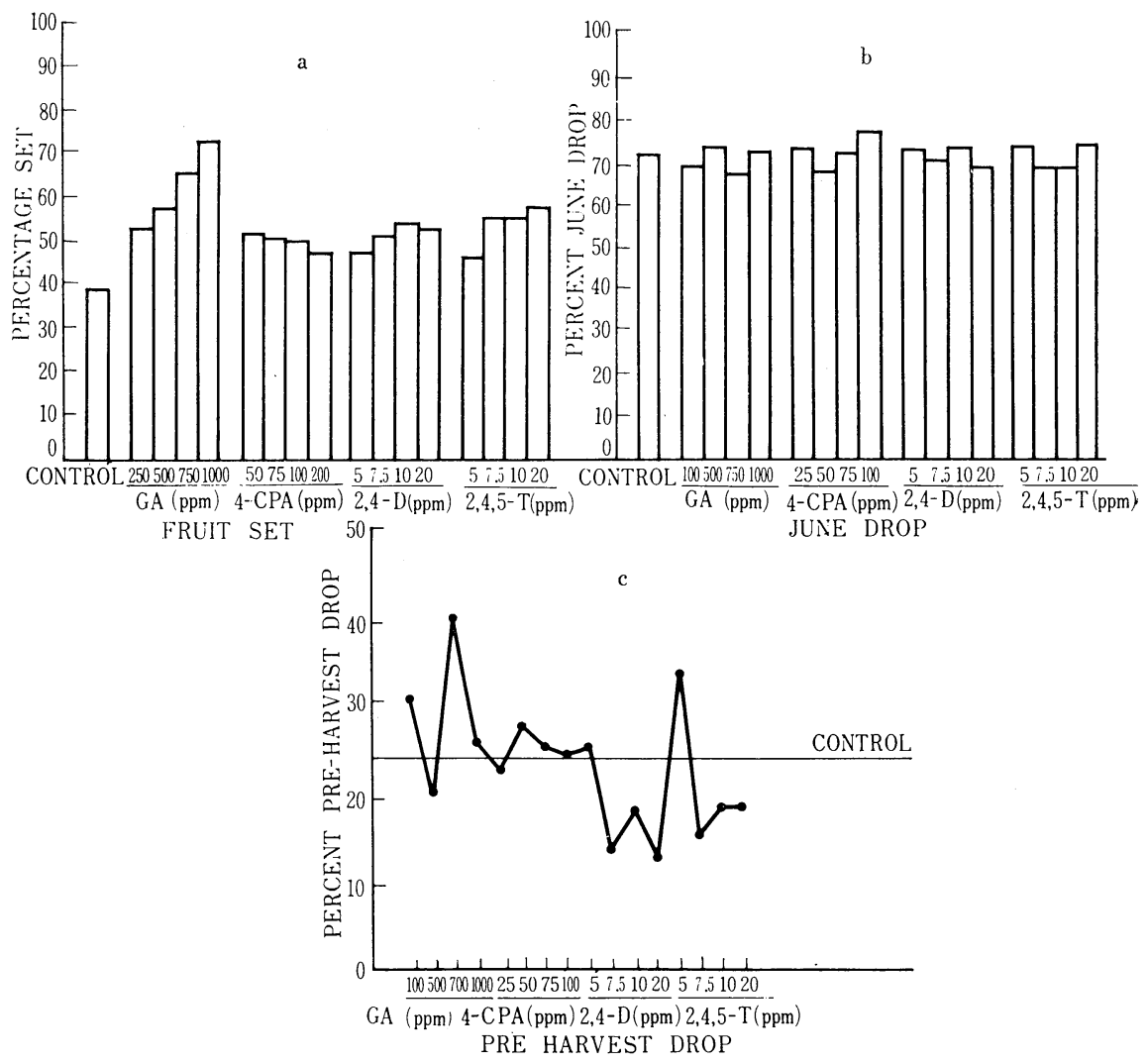

Fig. 1. Effect of different plant regulators on fruitset and fruitdrop in sweetlime. (1963) 
Table 2. Effect of plant regulators on physico-chemical composition of sweet lime.

(1963)

\begin{tabular}{|c|c|c|c|c|c|c|c|c|c|c|c|}
\hline Treatment & $\begin{array}{l}\text { Average } \\
\text { weight } \\
\text { of fruit }\end{array}$ & $\mid \begin{array}{c}\text { Fruit } \\
\text { dia- } \\
\text { meter }\end{array}$ & $\begin{array}{l}\text { Fruit } \\
\text { length }\end{array}$ & Juice & $\begin{array}{l}\text { Rind } \\
\text { Thick- } \\
\text { ness }\end{array}$ & T.S.S. & Acidity & $\begin{array}{c}\text { Total } \\
\text { sugars }\end{array}$ & $\begin{array}{l}\text { Reducing } \\
\text { sugars }\end{array}$ & $\begin{array}{l}\text { Non- } \\
\text { Reducing } \\
\text { sugars }\end{array}$ & $\begin{array}{c}\text { Vitamin } \bar{C} \\
(\mathrm{mg} / 100 \\
\mathrm{cc}) \\
\end{array}$ \\
\hline Control & $89.2^{\mathrm{g}}$ & $\begin{array}{c}\mathrm{cm} \\
5.77\end{array}$ & 5. 49 & 59.41 & 0.26 & $7.76^{\%}$ & $\begin{array}{r}\mathrm{mg} \\
42.88\end{array}$ & $9.02^{\%}$ & 4.36 & $4.42^{\%}$ & 73.23 \\
\hline $\begin{array}{lr}\text { GA } \quad 100 \mathrm{ppm} \\
500 \mathrm{ppm} \\
750 \mathrm{ppm} \\
1000 \mathrm{ppm}\end{array}$ & $\begin{array}{r}98.8 \\
104.6 \\
102.8 \\
90.1\end{array}$ & $\begin{array}{l}5.64 \\
5.78 \\
5.89 \\
5.91\end{array}$ & $\begin{array}{l}5.33 \\
5.40 \\
5.43 \\
5.73\end{array}$ & \begin{tabular}{l|}
46.8 \\
38.24 \\
43.77 \\
65.48
\end{tabular} & $\begin{array}{l}0.28 \\
0.29 \\
0.30 \\
0.31\end{array}$ & $\begin{array}{l}8.5 \\
8.4 \\
8.5 \\
7.5\end{array}$ & $\begin{array}{l}46.0 \\
57.38 \\
59.40 \\
60.37\end{array}$ & $\begin{array}{l}7.21 \\
6.84 \\
6.53 \\
6.26\end{array}$ & $\begin{array}{l}6.87 \\
6.35 \\
6.29 \\
6.07\end{array}$ & $\begin{array}{l}0.32 \\
0.50 \\
0.30 \\
0.17\end{array}$ & $\begin{array}{l}76.76 \\
85.10 \\
79.90 \\
86.40\end{array}$ \\
\hline $\begin{array}{r}4-\mathrm{CPA} \quad 25 \mathrm{ppm} \\
50 \mathrm{ppm} \\
75 \mathrm{ppm} \\
100 \mathrm{ppm}\end{array}$ & $\begin{array}{l}94.1 \\
80.2 \\
77.0 \\
74.7\end{array}$ & $\begin{array}{l}5.71 \\
5.46 \\
5.52 \\
5.28\end{array}$ & $\begin{array}{l}5.34 \\
5.07 \\
5.13 \\
4.88\end{array}$ & $\begin{array}{l}56.64 \\
58.10 \\
58.83 \\
55.69\end{array}$ & $\begin{array}{l}0.27 \\
0.30 \\
0.28 \\
0.25\end{array}$ & $\begin{array}{l}7.6 \\
7.0 \\
8.25 \\
8.0\end{array}$ & $\begin{array}{l}62.72 \\
59.30 \\
72.10 \\
32.85\end{array}$ & $\begin{array}{l}6.66 \\
6.53 \\
7.13 \\
6.63\end{array}$ & $\begin{array}{l}6.12 \\
6.44 \\
6.93 \\
6.45\end{array}$ & $\begin{array}{l}0.48 \\
0.08 \\
0.19 \\
0.17\end{array}$ & $\begin{array}{l}74.50 \\
78.70 \\
73.50 \\
73.90\end{array}$ \\
\hline $\begin{array}{l}2,4-\mathrm{D} \quad 5 \mathrm{ppm} \\
7.5 \mathrm{ppm} \\
10 \mathrm{ppm} \\
20 \mathrm{ppm}\end{array}$ & $\begin{array}{r}81.6 \\
88.3 \\
81.0 \\
104.0\end{array}$ & $\begin{array}{l}5.61 \\
5.73 \\
5.31 \\
5.87\end{array}$ & $\begin{array}{l}4.99 \\
5.20 \\
4.93 \\
5.47\end{array}$ & $\begin{array}{l}56.00 \\
60.36 \\
62.96 \\
53.46\end{array}$ & $\begin{array}{l}0.21 \\
0.21 \\
0.22 \\
0.29\end{array}$ & $\begin{array}{l}7.75 \\
8.0 \\
7.66 \\
8.00\end{array}$ & $\begin{array}{l}49.28 \\
46.72 \\
48.21 \\
42.66\end{array}$ & $\begin{array}{r}9.38 \\
11.06 \\
9.06 \\
8.83\end{array}$ & $\begin{array}{l}7.26 \\
7.63 \\
7.63 \\
7.63\end{array}$ & $\begin{array}{l}2.07 \\
\text { 3. } 26 \\
1.35 \\
1.14\end{array}$ & $\begin{array}{l}105.10 \\
100.20 \\
117.40 \\
111.10\end{array}$ \\
\hline $\begin{array}{r}2,4,5-\mathrm{T} 5 \mathrm{ppm} \\
7.5 \mathrm{ppm} \\
10 \mathrm{ppm} \\
20 \mathrm{ppm}\end{array}$ & $\begin{array}{l}78.9 \\
80.7 \\
78.1 \\
80.7\end{array}$ & $\begin{array}{l}5.30 \\
5.08 \\
5.26 \\
5.46\end{array}$ & $\begin{array}{l}4.94 \\
4.71 \\
4.78 \\
4.86\end{array}$ & $\begin{array}{l}53.61 \\
44.11 \\
52.49 \\
56.13\end{array}$ & $\begin{array}{l}0.23 \\
0.24 \\
0.26 \\
0.29\end{array}$ & $\begin{array}{l}8.00 \\
8.25 \\
7.00 \\
8.25\end{array}$ & $\begin{array}{l}36.48 \\
41.38 \\
31.13 \\
34.13\end{array}$ & $\begin{array}{l}7.76 \\
7.81 \\
6.51 \\
6.80\end{array}$ & $\begin{array}{l}6.99 \\
7.22 \\
5.32 \\
6.28\end{array}$ & $\begin{array}{l}0.73 \\
0.56 \\
1.16 \\
0.49\end{array}$ & $\begin{array}{l}68.10 \\
65.80 \\
66.50 \\
69.03\end{array}$ \\
\hline
\end{tabular}

over control was observed in 2,4,5-T (5 ppm).

Maximum reduction in drop was obtained by $2,4-\mathrm{D}$ (20 and $7.5 \mathrm{ppm}$ ) followed by $2,4,5-\mathrm{T}$ (7.5, 10 and $20 \mathrm{ppm}), 2,4-\mathrm{D}(10 \mathrm{ppm}), \mathrm{GA}(500 \mathrm{ppm})$ and 4-CPA (25 ppm).

Effect on Physico-chemical composition of fruit. The data are represented in Table 2. The size of the fruit was reduced or was equal to the size of control fruit in all the treatments other than GA. Size of the fruits increased with the increased concentration of GA. Rind thickness was increased by GA and 4-CPA treatments, whereas, 2,4-D and 2,4,5-T reduced it over control. Average weight of the fruit considerably increased by GA treatments except GA (1000 ppm). 4-CPA, 2,4-D and 2,4,5-T treatments reduced the average weight of the fruit.

Total sugars and non-reducing sugars were reduced by all the treatments but at the same time the reducing sugars were considerably increased over control by all the treatments especially 2,4-D and 2,4,5-T. Total acidity was increased by all GA, 2,4-D and 4-CPA treatments; it was only $2,4,5-\mathrm{T}$ which reduced it at all the concentrations. The effect on vitamin $\mathrm{C}$ content was also just the same i. e. 2,4,5-T decreased it and all other treatments increased it over control. Which would rather mean that $2,4,5-\mathrm{T}$ had detrimental effect on vitamin $\mathrm{C}$ content. Overall quality was improved by $2,4-\mathrm{D}$ treatments. Total soluble solids percentage was not affected much by any of these treatments.

\section{Discussion}

Keeping in view the presence or synthesis of auxins in the ovary to initiate its development and raising the auxin concentration in a plant to prevent abscission, the present study on sweet lime was undertaken. This study revealed that all the treatments had increased the fruit set, but considerable increase was obtained by GA (500, 750 and $1000 \mathrm{ppm}), 2,4,5-\mathrm{T}$ (7.5, 10 and $20 \mathrm{ppm})$ and $2,4-\mathrm{D}(10 \mathrm{ppm})$. Gibberellic acid proved comparatively more effective than other plant regulators. These findings are in conformity with the earlier findings ${ }^{7,8}$ on sweet lime. In present investigation, the plant regulators failed to check June drop in sweet lime. This agrees with the earlier findings ${ }^{7,8}$ on sweet lime. Considerable reduction in pre-harvest drop was obtained by $2,4-\mathrm{D}$ (7.5 and $20 \mathrm{ppm}), 2,4,5-\mathrm{T}$ (7.5, 10 and $20 \mathrm{ppm}), \mathrm{GA}$ (500 ppm) and 4-CPA 
(25 ppm). Early work $^{7)}$ reported that 2,4-D (10 and $20 \mathrm{ppm}$ ) and 2,4,5-T (5 and $15 \mathrm{ppm}$ ) had successfully controlled the pre-harvest drop in sweet lime. Similarly, maximum reduction in pre-harvest drop was noted in 2,4-D (20 ppm) followed by 2,4,5-T (10 ppm) and 4-CPA (100ppm) by Randhawa and Dhuria ${ }^{8)}$.

Increase in fruit size was recorded in GA (500, 750 and $1000 \mathrm{ppm})$ and 2,4-D (20 ppm). Similar results were reported by Randhawa and Dhuria ${ }^{8)}$ in sweet lime. Aqueous spray of 2,4,5-T and 2,4-D (20 ppm) at full bloom gave larger size fruit in sweet lime ${ }^{7}$. Sugar content and juice percentage were reduced by all the treatments other than 2,4-D. In fact only 2,4-D at all concentration improved the internal quality of sweet lime fruits. Rind thickness was increased by all GA and 4-CPA treatments but reduced by 2,4-D and 2,4,5-T. Gibberellin treated fruits were lemon shaped and had prominent mamilla. Similar observations were made in sweet lime by earlier workers ${ }^{8)}$. Adverse effect on quality by the application of GA has been reported in Coorg mandarins ${ }^{9)}$.

From the foregoing discussion GA at 750 and $1000 \mathrm{ppm}$ and $2,4-\mathrm{D}$ and $2,4,5-\mathrm{T}$ at 7.5 to $20 \mathrm{ppm}$ can be recommended for increasing fruit set and reducing fruit drop respectively in sweet lime.

\section{Acknowledgement}

The authors are grateful to Dr. S. K. MukherjeE, then Head of Department of Horticulture I.A.R.I. Delhi, for providing facilities and encouragement and to the staff members of Laboratory of Pomology, University of Chiba, Matsudo City (Japan), for going through the manuscript and helping in writing the abstract in Japanese.

\section{Literature cited}

1. A. O. A.C. 1960. Official and tentative methods of analysis. Association Official Agric. Chem. Washington D. C.

2. ERICKSON, L. C. 1951. Effect of 2,4-D on drop of sound and unsound Washington Navel Orange. Proc. Amer. Soc. Hort. Sci. $58: 48$ -62 .

3. FitTing, H. 1909. Die Boeinflusing der Orchidean Bluten durch die Bestanbung und durch andere Umstande. Zeitsshr Bot. 1:186.

4. GUSTAFSON, F. G. 1936. Inducement of fruit development by growth promoting chemicals. Proc. Nat. Acad. Sci. 22 : 628-636.

5. Leopold, A. C. 1955. Auxin and plant growth. Univ. of Calif. Press, Berkley and Los Angeles, U. S. A.

6. OVERBEEK, J.Van. 1962. Endogenous regulators of fruit growth. pp. 1037 1039 (ed. S. G. Younkin). Plant Science Symposium on fruit set Campbell Soup Co. Camden, N. J.

7. RANDHAWA, G. S., J.P.SINGH and H. S. DHURIA.
1959. Effect of GA, 2,4-D and 2,4,5-T on fruit set, drop, size and total yield in sweet lime (Citrus limettioides Tanaka) Ind. J. Hort. $16: 206-209$.

8. RANDHAWA, G. S. and H. S. DHURIA. 1965. Effect of plant regulators on fruit set and fruit drop in Citrus, III. Sweet lime (Citrus limettioides TANAKA). Ind. J. Hort. $22: 131$ -139 .

9. RODRIQUES, J. and others. 1963. Effect of preharvest spray of plant growth regulators on Coorg mandarin (Citrus reticulata BLANCO) and their storage studied with and without wax coating. Food Science Mysore, 12:336 -340 .

10. Stewart, W.S., H. Z. HiELD and B. L. BraNNAMAN. 1952. Effect of 2,4-D and related substances on fruit drop yield, size and quality of Valencia orange. Hilgardia $21: 301-329$.

11. StewArT, W. S. and L. J. KLOTZ. 1947. Some effects of 2,4-D on fruit drop and morphology of oranges. Bot. Gaz. 109 : 150-152. 
スィートライムの結実と生理的落果に関する研究

B.S. チュンダワット・G.S. ランダワ

(インド国立農業研究所, ニューデリー, インド)

摘要

スィートライム(Citrus limettioides TANAKA) の結 実と落果についてニューデリー (インド北部) で1962 年 から 1964 年の間実験を行なつた。種々の濃度の GA, 4-CPA，2４-D，2,4，5-T が結実, 落果, 果実の品質に特 よぼす影響を検討した結果，GA $750 ， 1,000$ ppm が最
高の結果率を示し，2, 4, 5-T 20 ppm, GA 500 ppm, 2, 4, 5-T 7.5, 10 ppm がこれに次いで結果率を上げた。 植物生長調節物質はジュンドロップの防止には無効で あつたが，2,4-D 7.5,20 ppm と 2,4,5-T 7.5, 10， $20 \mathrm{ppm}$ は収穫前の落果防止にはきわめて有効であつた。 